\title{
Effect on Partial Replacement of Fine Aggregate and Cement by Waste Marble Powder/ Granules on Flexural and Split Tensile Strength
}

\author{
Rishi $^{1}$, Dr. Vanita Aggarwal ${ }^{2}$ \\ *(P.G Student: Civil Engineering Department, Maharishi Markandeshwar University, Mullana(Ambala), \\ Haryana, India \\ ** (Professor: Civil Engineering Department, Maharishi Markandeshwar University, Mullana (Ambala), \\ Haryana, India
}

\begin{abstract}
Marble as a building material especially in palaces and monuments has been in use for ages Many studies have been reported in literature on the performance of the concrete containing waste marble dust or waste marble aggregate. It can be seen that combination of marble dust and other ingredients has modulus or compressive strength higher than alone for 7 days and 28 days respectively. The use of high proportion of marble dust increases the strength of cement paste..This study shows the experimental investigations on the replacement of cement and sand both partially \& combined with the waste marble powder/waste marble granules in which, by the partial replacement of cement and sand, the compressive, flexure and split-tensile strength get increased up to a certain percentage but get decreased with the combined replacement of combination of cement \& sand.
\end{abstract}

Keywords: Fine Aggregate, flexure strength, , OPC 43 Grade, split tensile strength, WMP

\section{Introduction}

Cement based material are the most abundant materials in the world. Due to the high in demand of natural resources our engineers $\&$ architect has growing interest in sustainable development by choosing the material which are more sustainable that is why the green building concept is emerging in our country.It is very eco friendly \& save the environment by using waste products generated by industries such as micro silica rice husk etc. it is realistic that a technology can be developed which can reduced the carbon dioxide emission related to concrete production. In India the marble \& granite are the most thriving industries. Marble waste when dumped on open land affects adversely the productivity of land as it reduces the porosity and affects ground water recharge. The marble is widely used in buildings due to its beauty, strength \& resistance to fire. S.S Suresh et al (2013)[1] conducted study on concrete using marble dust in varying proportions. Marble sludge powder was obtained in wet form directly taken from deposits of marble factories, Northern India. Wet marble sludge powder was dried before the sample preparation. Marble dust was sieved from $1 \mathrm{~mm}$ sieve. The high content of various minerals confirmed that the original stones were Marble and limestone. The dust was also tested to identify the absence of organic matter, thus confirming that it could be used in concrete mixtures and its physical characteristics. With the help of compressing machine the compressive strength of block were determined. Ordinary Portland cement (43Grade) with 28 percent normal consistency with specific surface 2100 $\mathrm{cm}^{2} / \mathrm{g}$ conforming to IS: 8112-1989 was used..Sachin (2010)[2] used Marble Powder and artificial sand or manufactured sand as partial replacement for natural sand to conduct their study on mechanical behavior of concrete. Tests were conducted using natural sand, manufactured sand, marble dust with equal amount of cement, coarse aggregate and water. Sieve analysis was carried out on fine sand.A further step Akbulut et al (2011)[3] found in their studies that the concrete containing waste marble dust or waste marble aggregate, such as its addition into self-compacting concrete as an admixture or sand as well as its utilization in the mixture of asphaltic concrete and its utilization as an additive in cement production, the usage ofmarble as a coarse aggregate and as a fine aggregate passing through $1 \mathrm{~mm}$ sieve.Baboo Rai et al (2011) [4]conducted the study on cubes of mortar (1:3) with varying partial replacement of cement with the same amount of WMP and tested at three different intervals of curing. Also cubes of (1:3) mortar with partial replacement of sand with the same amount of WMP Granules were casted and their strength was evaluated after 7, 14, and 28 days in different lots. Their results were compared with those of standard (1:3) mortar and concrete cubes.

\section{Methodology}

To investigate the effect of waste marble on concrete, four different specimens were casted and tested at an interval of 7 days and 28 days. After the evaluation of their strength the results were compared to control mix concrete. 


\section{Mix Proportion}

\begin{tabular}{|c|c|c|c|c|}
\hline Sr. No & Cement & Sand & Marble Powder & Mix designation \\
\hline 1 & $100 \%$ & $100 \%$ & $0 \%$ & MX0(control) \\
\hline 2 & $100 \%$ & $90 \%$ & $10 \%$ & MX1(Sand) \\
\hline 3 & $90 \%$ & $100 \%$ & $10 \%$ & MX2(cement) \\
\hline 4 & $90 \%$ & $90 \%$ & $20 \%$ & MX3(cement and sand) \\
\hline
\end{tabular}

A design mix m-25 grade with w/c ratio 0.43 was adopted to prepare test samples. The code used for the design mix is IS: 10262:1982, and for Coarse and Fine aggregate the code IS: $383: 1970$ chosen to satisfy the specification requirements.

\section{Results And Discussion}

The Results Obtained at 7 and 28 days by Replacement of WMP are as follows:

Table: Flexural Strength after 7 Days

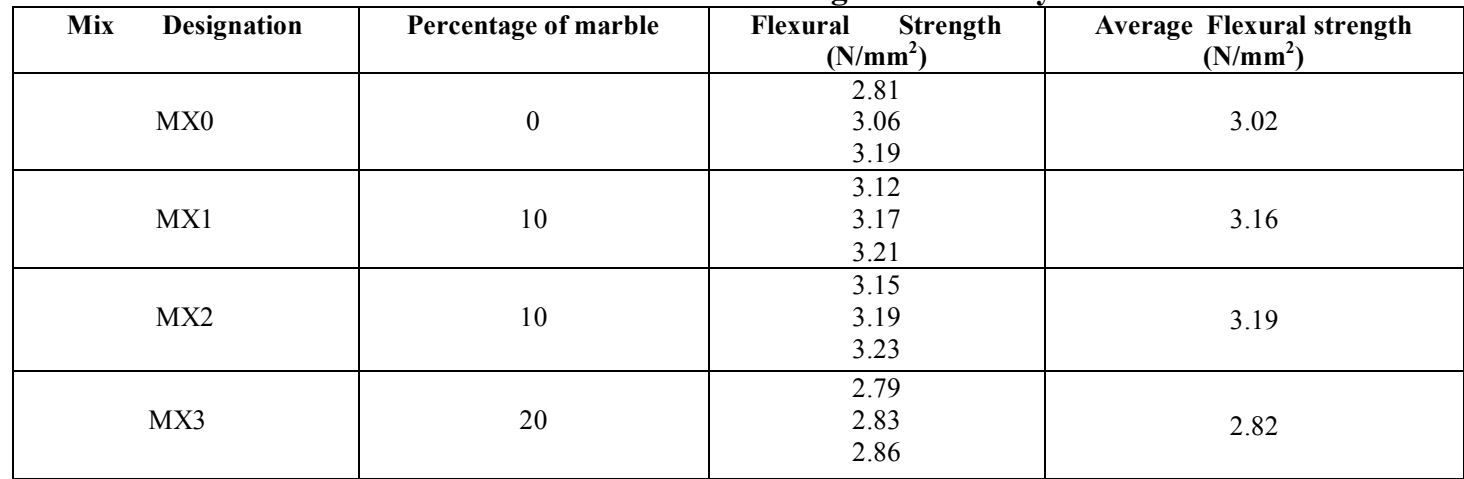

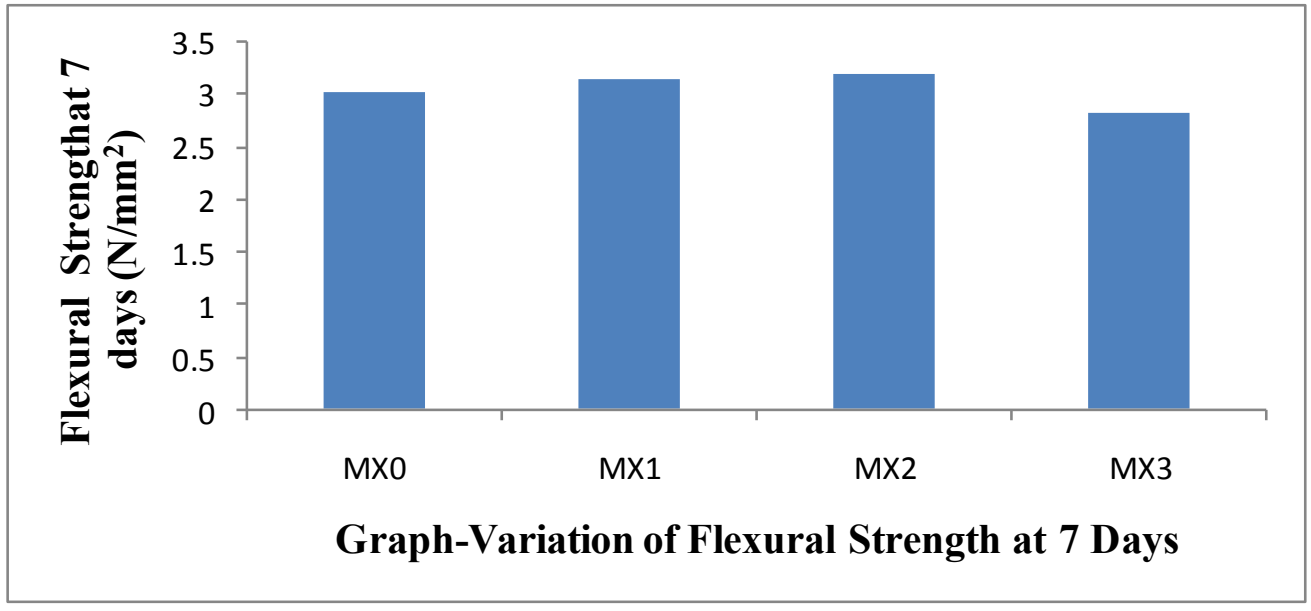

Table: Flexural Strength at 28 Days

\begin{tabular}{|c|c|c|c|}
\hline Mix Designation & Percentage of marble & $\begin{array}{c}\text { Flexural Strength } \\
\left(\mathbf{N} / \mathbf{m m}^{2}\right)\end{array}$ & $\begin{array}{l}\text { Average Flexural strength } \\
\left(\mathrm{N} / \mathrm{mm}^{2}\right)\end{array}$ \\
\hline MX0 & 0 & $\begin{array}{r}4.60 \\
4.68 \\
4.82\end{array}$ & 4.70 \\
\hline MX1 & 10 & $\begin{array}{l}4.78 \\
4.94 \\
5.05\end{array}$ & 4.92 \\
\hline MX2 & 10 & $\begin{array}{l}4.69 \\
4.76 \\
4.86\end{array}$ & 4.77 \\
\hline MX3 & 20 & $\begin{array}{l}4.30 \\
4.42 \\
4.54\end{array}$ & 4.42 \\
\hline
\end{tabular}




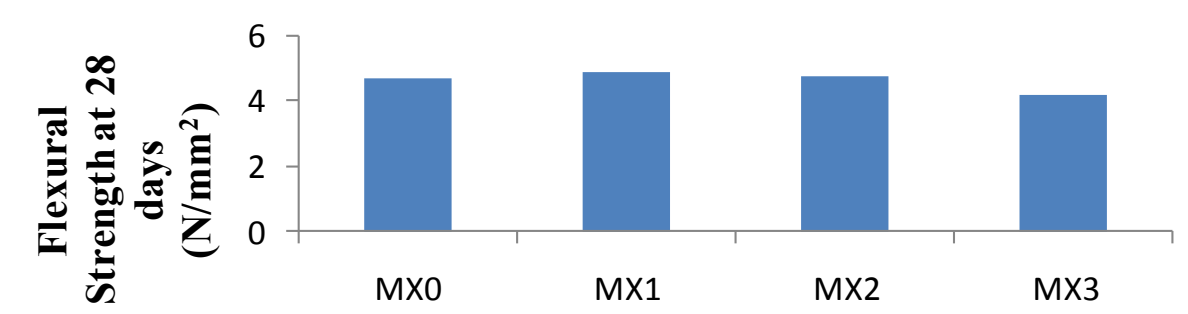

Graph-Variation of Flexural Strength at 28 days

It can be seen from the above tables and figures that the Flexure strength for the mix containing $10 \%$ WMP in cement is increased by $2 \%$ and for $10 \%$ replacement of sand the Flexure Strength in increased by $5 \%$ but it decreases for Mix containing 20\% WMP against cement (10\%) and sand(10\%) by $11 \%$.

Table: Split Tensile Strength after 7 Days

\begin{tabular}{|c|c|c|c|c|}
\hline Mix & Designation & Percentage of marble & $\begin{array}{c}\begin{array}{c}\text { Split Tensile Strength } \\
\left(\mathrm{N} / \mathrm{mm}^{2}\right)\end{array} \\
\end{array}$ & $\begin{array}{l}\text { Average Split strength } \\
\left(\mathbf{N} / \mathbf{m m}^{2}\right)\end{array}$ \\
\hline & MX0 & 0 & $\begin{array}{l}2.03 \\
2.16 \\
2.29\end{array}$ & 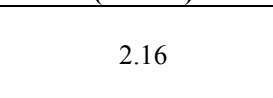 \\
\hline & MX1 & 10 & $\begin{array}{l}2.16 \\
2.35 \\
2.42\end{array}$ & 2.31 \\
\hline & MX2 & 10 & $\begin{array}{l}2.29 \\
2.48 \\
2.67\end{array}$ & 2.48 \\
\hline & MX3 & 20 & $\begin{array}{l}1.91 \\
1.97 \\
2.10\end{array}$ & 1.99 \\
\hline
\end{tabular}

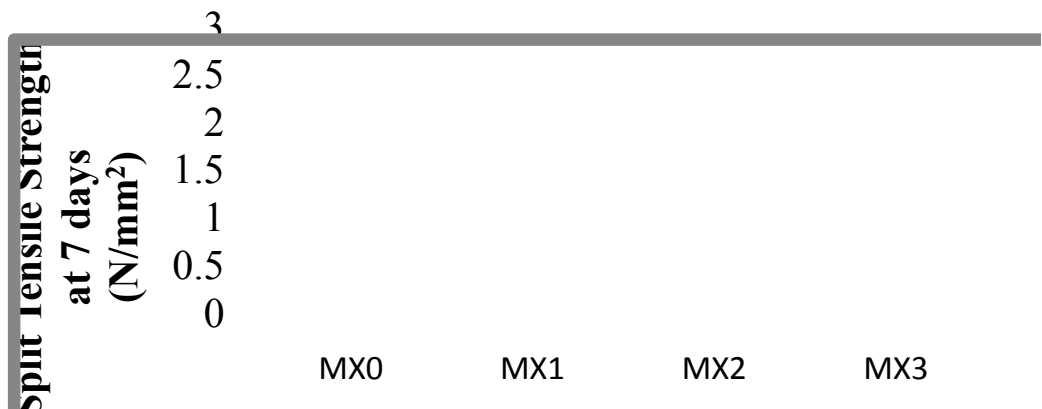

\section{Graph:Variation of Split Tensile Strength :}

Table: Split Tensile Strength at 28 Days

\begin{tabular}{|c|c|c|c|c|}
\hline Mix & Designation & Percentage of marble & 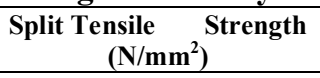 & $\begin{array}{c}\text { Average Split strength } \\
\left(\mathbf{N} / \mathbf{m m}^{2}\right)\end{array}$ \\
\hline & MX0 & 0 & $\begin{array}{l}3.56 \\
3.75 \\
3.94 \\
\end{array}$ & 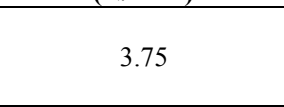 \\
\hline & MX1 & 10 & $\begin{array}{l}4.14 \\
4.20 \\
4.33 \\
\end{array}$ & 4.22 \\
\hline & MX2 & 10 & $\begin{array}{l}4.07 \\
4.20 \\
4.26\end{array}$ & 4.17 \\
\hline & MX3 & 20 & $\begin{array}{l}3.18 \\
3.31 \\
3.50\end{array}$ & 3.33 \\
\hline
\end{tabular}




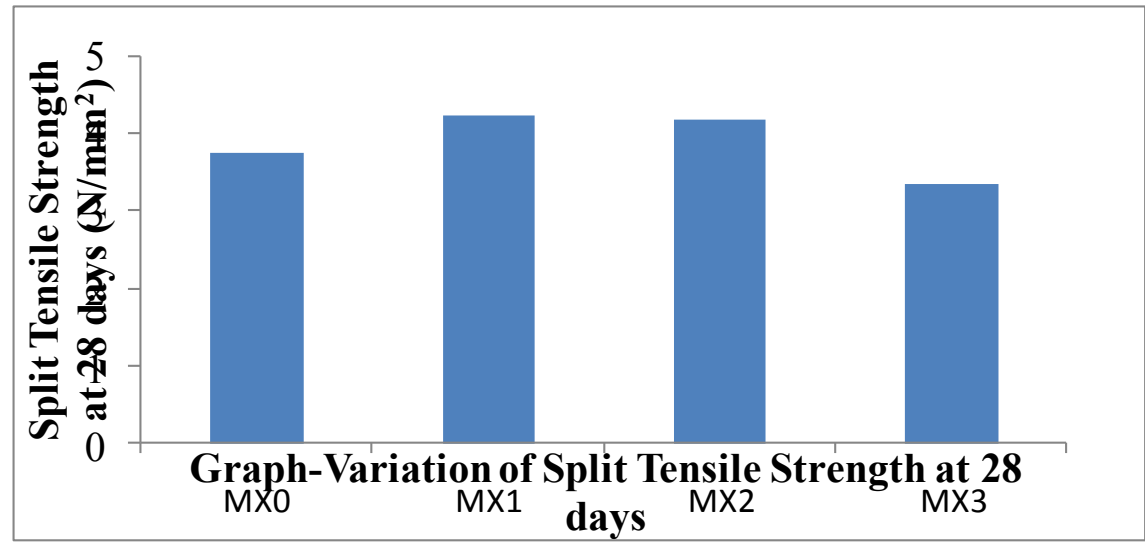

It can be seen from the above tables and figures that the split tensile strength for the mix containing $10 \%$ WMP against cement is increased by $11 \%$ and for $10 \%$ replacement of sand the split tensile Strength in increased by $12 \%$ but it decreases for the Mix containing $20 \%$ WMP against cement $(10 \%)$ and sand $(10 \%)$ by $11 \%$.

\section{Conclusion}

The result obtained in the present study indicates that partially it is feasible to replace the fine aggregate and cement by waste marble powder for improving the strength characteristics of concrete but the strength get decreased when replace the fine aggregate and cement combined by waste marble powder by $20 \%$, thus the combination against cement and sand cannot be replaced. The optimum dosage of replacement by WMP is found to be $10 \%$ against sand as this mix gave maximum Flexural and Split Tensile Strength at 28 days.

\section{References}

[1]. S.Suresh and ShaktinathDas"Green cement for sustainable concrete using marble dust" Department of ChemicalEngineering,MaulanaAzad NationalInstituteof Technology. International conference on global scenario in environment and energy March 2013.

[2]. Sachin2010:" Effect of the lime content in marble powder for producing high strength concrete" Vol. 8, No. 4, April 2013

[3]. AkbulutH andGürerC(2007). "Useofaggregates produced frommarble quarry waste in asphalt pavements". Build. Environment, 42(5): 1921-1930.

[4]. Baboo Rai, Khan Naushad H, Abhishek Kr, Tabin Rushad S, Duggal S.K, Volume 1, No 4, 2011, Influence of Marble powder/granules in Concrete mix"

[5]. IS: 3831970, Specification for Coarse and Fine Aggregate from Natural Sources for Concrete-Bureau of Indian Standards, New Delhi.

[6]. IS: 102621982, Recommended Guidelines for Concrete Mix Design—Bureau of Indian Standards, New Delhi. 